REM WORKING PAPER SERIES

\title{
Does the Introduction of Stock Exchange Markets Boost Economic Growth in African Countries?
}

António Afonso, Max Reimers

\section{REM Working Paper 0160-2021}

January 2021

\author{
REM - Research in Economics and Mathematics \\ Rua Miguel Lúpi 20, \\ 1249-078 Lisboa, \\ Portugal
}

ISSN 2184-108X

Any opinions expressed are those of the authors and not those of REM. Short, up to two paragraphs can be cited provided that full credit is given to the authors.

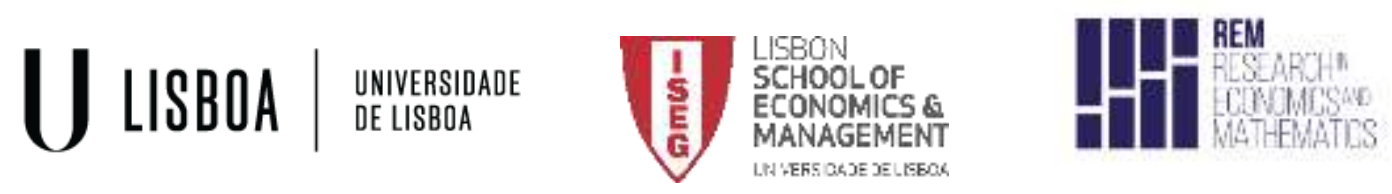




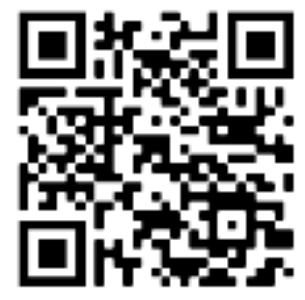

REM - Research in Economics and Mathematics

Rua Miguel Lupi, 20

1249-078 LISBOA

Portugal

Telephone: +351 - 213925912

E-mail: rem@iseg.ulisboa.pt

https://rem.rc.iseg.ulisboa.pt/

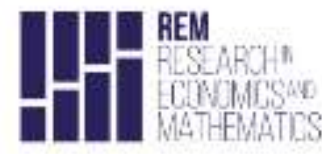

https://twitter.com/ResearchRem

https://www.linkedin.com/company/researchrem/

https://www.facebook.com/researchrem/ 


\title{
Does the Introduction of Stock Exchange Markets Boost Economic Growth in African Countries?*
}

\author{
António Afonso $\$$.
}

Max Reimers ${ }^{+}$

January 2021

\begin{abstract}
We assess whether the introduction of private equity capital markets effects economic growth in African countries. We address this issue by focussing on stock exchange markets as the predominant type of new equity markets, using a Diff-in-Diff regression method. The analysis uses a panel data set from $48 \mathrm{Sub}$-Saharan countries over the time range of 1970-2018. 23 countries are part of the "treated" group - which introduced international stock exchanges - and 25 "untreated" countries serve as the control group. Our results show that when compared with the time period prior to the introduction of stock exchange markets, GDP per capita rises by the amount of 532 US\$ (around $40 \%$ of the Sub-Saharan average) after the introduction of equity capital markets in the treated countries. Over the ten years post introduction, the effect is hump-shaped, with effects becoming statistically significant from the first year after implementation, with a peak in Year 5, and it then becomes statistically insignificant from then onwards.
\end{abstract}

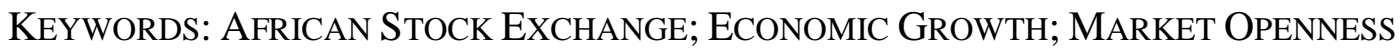
JEL CODES: C32; G15; N17.

\footnotetext{
* This work was supported by the FCT (Fundação para a Ciência e a Tecnologia) [grant number UIDB/05069/2020]. The opinions expressed herein are those of the authors and not necessarily those of their employers.

\$ISEG - School of Economics and Management, Universidade de Lisboa; REM - Research in Economics and Mathematics; UECE - Research Unit on Complexity and Economics. UECE/REM is supported by FCT. R. Miguel Lupi 20, 1249-078 Lisbon, Portugal. email: aafonso@iseg.ulisboa.pt.

+ ISEG - School of Economics and Management, Universidade de Lisboa. email: maxreimers@aln.iseg.ulisboa.pt.
} 


\section{INTRODUCTION}

The correlation between economic growth and equity capital markets has been brought to evidence in different empirical studies in the past. Fuchs-Schündeln and Funke (2001), focussing on existing, but liberalised stock markets concluded that there is a temporary positive effect of such liberalisation on real GDP growth. These authors based their study on a sample of 26 countries from all over the world. The empirical evidence was confirmed for the countries from the Middle East and North Africa (henceforth MENA region, Naceur, et al., 2008) where the focus of the research was centred on the pre-and post-development of those economies that introduced equity capital markets. To date, the effect of introducing stock exchange markets as a determinant of economic growth has not been researched for the case of Sub-Saharan Africa. This paper addresses this issue, focussing on stock markets as the predominant type of new equity markets.

The motivation behind the research question "Does the introduction of stock exchange markets boost economic growth in African countries?" lies within the fact that most of the Sub-Saharan countries implemented their stock exchange markets very recently. The countries mainly belong to the developing countries group, where it is of interest to analyse whether the introduction of such financial markets has significant positive effects on economic growth. The introduction of international stock exchanges affect GDP throughout different channels. They-improve accounting standards and disclosure transparency, enforce property rights, strengthen legal and judicial systems for investor protection, attract foreign and local equity capital, and increase the domestic institutional investor base.

A useful empirical identification strategy for assessing these effects is by using a Diff-in-Diff approach. The source of variation in this setting is derived from the comparison of economic growth prior to, and past the introduction of stock exchange markets, and from the comparison of a group of treated countries (that implemented stock markets) versus control countries (that did not implement stock markets). When estimating the coefficient for "treated" countries we control for variables such as the value added over time for different sectors, foreign direct investment net inflows, and domestic credit to private sector, as well as net official development assistance. This is to ensure that the common trend assumption is fulfilled. These control variables directly correlate 
with both GDP per capita and the introduction of international stock exchange markets and thus they are necessary to estimate unbiased coefficients.

Our results are robust and presume that the introduction of international stock exchange markets have a significant impact on the level of GDP per capita. For treated countries, the GDP per capita increases around 532 US\$ post market implementation. In economic terms, this is considerable, given that it constitutes an increase greater than $40 \%$ when compared to the average GDP per capita of all Sub-Saharan countries over the period of 1970-2018. We then repeat the regression to measure the impact of an introduction of an international stock exchange on the GDP per capita growth. In this approach, we find the introduction of international capital markets on GDP per capita growth to be significant at a 5\% level when including control variables. Post implementation, treated countries display a growth rate of $0.9 \%$. This positive relationship is coherent with the results of Fuchs-Schündeln and Funke (2001) who carried out a similar regression on market liberalisation, however they controlled for policy reforms.

Based on our results, we deepen our analysis by assessing how variable this effect is over time. To do this, we apply the empirical strategy of Fuchs-Schündeln and Funke (2001). This way we can capture whether the effect of introducing stock markets on economic growth is limited over time, or is sustainable in the end. Our regression suggests that at the start, in the very year of market introduction, the effect on the GDP per capita level is statistically non-significant, with a coefficient of around 407 US\$. It then follows a hump-shape, by starting to be statistically and economically significant from Year 1, after the introduction onwards, and then reaches a peak in Year 5. This result is coherent with the work of Fuchs-Schündeln and Funke (2001), who found that the effect of liberalisation on GDP per capita growth reaches its peak in Year 4. However, the effect seems to be limited to the first five years after introduction. From Year 6 onwards, the effect is no longer statistically significant and the coefficient decreases, which implies that the long term effect of the introduction of international stock exchange markets on GDP per capita is limited to the results achieved within the first five years.

The remainder of the paper is organised as follows. Section 2 summarises the relevant literature. Section 3 provides a brief overview of stock exchange markets and the 
economic status of Sub-Saharan countries in general. Section 4 describes the empirical methodology and is followed by the results in Section 5. Finally, Section 6 concludes.

\section{REVIEW OF THE LITERATURE}

Within the economic development literature, many studies have assessed the potential effects of international stock markets on economic growth. The purpose of this section is to summarise the potential channels through which the implementation of equity capital markets is suggested to affect GDP per capita and GDP per capita growth, namely: enhancing complementary markets and market infrastructure, attracting domestic and foreign capital by providing a higher degree of market openness, a higher transparency of disclosure of external accounting and a general improvement of accounting standards, the strengthening of legal and judicial systems for investor protection followed by the enforcement of property rights, as well as other channels.

Several studies focussed more on the theoretical background of the Solow growth theory model (Romer, 1996). Greenwood and Smith (1997) assessed whether equity capital acts as a driver for capital accumulation. Their research focuses on an agent's savings behaviour in the presence of equity capital markets and its positive impact on the saving rate of an economy. One conclusion is that equity markets increase the growth rate of an economy relative to the optional bank financing if, and only if agents are risk averse.

Levine and Zervos (1998) predicted that stock market liquidity and banking development have a positive impact on economic growth, capital accumulation and productivity. They performed an empirical analysis taking into account several economic growth indicators as dependent variables, namely: output growth, capital stock growth, productivity growth, and savings. Their research promotes a strong link between liquidity and capital accumulation, whereas the stock market size itself and its openness are not specifically linked to growth.

Nowbutsing and Odit (2009) carried out a time series analysis for Mauritius. They highlight that in this country alone (which liberalised stock markets in 1988), an increase in stock market liquidity increases GDP per capita growth. In contrast to the study of Levine and Zervos (1998), the size of equity capital markets correlates significantly with GDP per capita growth. Nowbutsing and Odit (2009) carried out a time series analysis of years followed by the introduction of capital markets, constructing an error correction 
model. In this study, a $10 \%$ increase in the size of capital markets is associated with an increase of $1.3 \%$ of real GDP per capita. Cuza (2012) assessed the impact of stock market development on GDP growth, using a single country (Romania) analysis as well. He applied a VAR model which includes the GDP growth rate, market capitalisation, stock traded value, and real investment (Cuza 2012). Similar to Nowbutsing and Odit (2009), Cuza's results imply that the level of market capitalisation does not have a significant impact on GDP growth. On the other hand, he finds a direct relationship between an increase of market capitalisation and real investment and therefore an indirect impact on GDP growth.

The main study that serves as inspiration for this research is that of FuchsSchündeln and Funke (2001). Their sample comprises 12 Asian, 7 Latin American, 5 African, and 3 European countries. They focus on liberalising existing markets instead of introducing stock exchange markets. In their paper they focus on an empirical analysis of the economic situation of three different time periods: (i) prior to liberalisation, (ii) the year of liberalisation, and (iii) the post liberalisation period. Their results show that real per capita GDP growth exhibits a higher average during the period of financial liberalisation. On the other hand, this research uses a similar empirical identification strategy to test the effects of newly-introduced stock exchange markets purely in SubSaharan countries. Another difference is that in this study, Sub-Saharan countries which did not introduce capital markets are added as control variables, in order to add value by comparing the economic development of non-treated vs. treated countries which actually introduced stock exchange markets, mainly during the late 1980s up until recently.

In the first part of their work, using a sample of 27 countries, Fuchs-Schündeln and Funke (2001) analyse the effect of these countries opening their equity stock markets to foreign investors. Firstly, they regress GDP growth on liberalisation dummies, country specific constants, and year dummies. Afterwards, the authors additionally control for variables which could bias their results if they were omitted, examples being trade openness, stock market size, and private investment - which make the estimation very robust. This is mainly to ensure the validity of the common trend assumption underlying Diff-in-Diff analyses. Although trade openness is not significant, stock market size and private investment play a significant role. 
In the second part of their work, they assess empirically the role of institutional factors. Taking GDP growth as dependent variable, they choose the change of contract enforceability, change in national risk, and trade openness as explanatory variables. The time range under study is one-year prior to and five-years post liberalisation. Their regression justifies that an improved contract enforceability prior to the liberalisation of international financial markets is positively correlated with GDP growth. Lower national risk has similar effects, albeit less significant than a functioning institutional framework for the variable of contract enforceability.

Additionally, a high quality level and a timely disclosure of firms' external accounting needs to be in place. This is necessary to provide investors with a minimum of information to assess the value of the securities being traded on public offerings and on the secondary stock market. Bad functioning of the accounting system and weak and delayed disclosure creates a moral hazard and permits insiders to take advantage of price movements. The existence of an efficient judiciary enforcement of sanctions against insider trading increases the positive effects of market liberalisation on growth. FuchsSchuendeln and Funke (2001) implement an institutional indicator of the prohibition of insider trading, however the coefficient is statistically insignificant.

In the work of Yiew et al. (2018), a panel data sample of 95 developing countries is assessed throughout the years of 2005-2013. These authors use foreign direct investment (FDI) as a control variable. Their empirical approach applies the fixed effect model regression to support the research question and their model proposes a quadratic relationship of Official Development id (ODA) with economic growth. Indeed, they finds a U-shape relationship between ODA and economic growth. The result of their research implies that ODA has a negative effect in the short run, whereas it has a positive correlation with economic growth in the long run. Nonetheless, economic growth is less likely to depend on ODA. Their results show that for a $1 \%$ increase in private FDI, economic growth increases by $0.036 \%$ for the respective model. We will resort to the use of ODA as one of the control variables in our analysis. This choice is also brought about by the fact that other studies, such as that of Mallik (2008), also confirm that ODA and real GDP are negatively correlated. These authors achieve this result by using panel cointegration techniques with data from the Central African Republic, Niger, Malawi Togo, Sierra Leone, and Mali. In the short term, net ODA is not significant for economic growth 
per capita for all the countries, except for Niger. In the long run, foreign aid even has a significant negative effect on real GDP. In general, it can be said that several studies on the relationship between net ODA and GDP per capita growth have been carried out - all with different conclusions. In our analysis, the effect of the implementation of equity capital markets on GDP per capita is crucial to control for FDI and ODA.

The assessment of Coulibali and Gapka (2017) is closely related to the topic of ODA. These authors carried out an empirical analysis of 36 Sub-Saharan countries over the period of 1996-2013. They capture the effect of financial openness (which is measured by the ratio of foreign direct investment inflows and outflows to portfolio equity flows) on GDP growth. In addition, they also measure the effect of the institutional quality of property rights with an index which takes into account the independence of judicial authority, the presence of corruption, and the capability of enforcing contracts for firms and individuals. Their sample countries are divided into two categories: rich in natural resources (16 countries) and poor in natural resources (20 countries). PMG regressions are used to capture the effects of the independent variables on economic growth. One of the various results shows that countries which benefit hugely from the existence of natural resources have, on average, a score for private property rights which is less than that of those Sub-Saharan countries that do not have many natural resources.

Nevertheless, the minimum security of property rights is necessary for international capital flows to Sub-Saharan countries to be fruitful. Domestic and foreign investors need to be protected by laws from expropriation. This issue is also confirmed by a working paper of the Bank of International Settlements (BIS), which stresses the importance of implementing efficient policies when establishing viable capital markets. Six key drivers of capital market development are defined, namely: i) greater respect for market autonomy, ii) strengthening legal and judicial systems, iii) enhancing regulatory independence and effectiveness, iv) enlarging the domestic institutional investor base; v) pursuing bi-directional opening to international participation while preparing for spillovers and vi) developing complementary markets and market infrastructures (Acharya, et al., 2019). 


\section{SUB-SAHARAN AFRICAN COUNTRIES AND THEIR STOCK EXCHANGE MARKETS}

\subsection{Countries and the time-range of the analysis}

We focus on 48 Sub-Saharan African countries from 1970 to 2018. All data is retrieved from the World Bank data repository of world development indicators (WDI). ${ }^{1}$ For each country, the date of equity capital markets introduction and the number of listed companies were retrieved from the respective countries' stock exchange homepages (see Table I).

\section{TABLE I - SUB-SAHARAN COUNTRIES UNDER STUDY²}

\begin{tabular}{c|c|c|c}
\hline \hline $\begin{array}{c}\text { Treated } \\
\text { Countries }\end{array}$ & $\begin{array}{c}\text { Introduction } \\
\text { of CM }\end{array}$ & $\begin{array}{c}\text { Listed } \\
\text { Companies 2020 }\end{array}$ & $\begin{array}{c}\text { Stock } \\
\text { Exchange }\end{array}$ \\
\hline Botswana & 1989 & 36 & BSE \\
\hline Cote d' Hivoire & 1998 & 46 & BRVM \\
\hline Cameroon & 2001 & 2 & DSX \\
\hline Cape Verde & 2005 & 12 & BVC \\
\hline Gabon & 2003 & 1 & CEMAC \\
\hline Ghana & 1990 & 31 & GSE \\
\hline Lesotho & 2016 & 0 & MSM \\
\hline Mozambique & 1999 & 11 & BVM \\
\hline Mauritius & 1988 & 88 & SEM \\
\hline Malawi & 1995 & 14 & MSE \\
\hline Namibia & 1992 & 7 & NSX \\
\hline Rwanda & 2008 & 9 & RSE \\
\hline Sudan & 1994 & 53 & KSE \\
\hline Somalia & 2015 & 2 & SSE \\
\hline Swaziland & 1990 & 5 & ESE \\
\hline Seychelles & 2012 & 24 & MERJ \\
\hline Tanzania & 1998 & 28 & DSE \\
\hline Uganda & 1997 & 17 & USE \\
\hline Zambia & 1994 & 26 & LuSE \\
\hline Kenia & 1954 & 55 & NSE \\
\hline Nigeria & 1960 & 215 & NiSE \\
\hline Zimbabwe & 1948 & 63 & ZSE \\
\hline South Africa & 1887 & 352 & JSE \\
\hline Sowra Ling
\end{tabular}

Source: Listed companies retrieved from the World Bank Indicator Databank.

\footnotetext{
${ }^{1}$ The raw data was retrieved from the WDI world bank indicator homepage https://databank.worldbank.org/

2 The control countries are: Angola, Burundi, Benin, Burkina Faso, The Dem. Rep. of Congo, The Rep of Congo, Comoros, Eritrea, Ethiopia, Guinea, Guinea Bissau, Gambia, Equatorial Guinea, Liberia, Madagascar, Mali, Mauretania, Niger, Senegal, Sierra Leone, South Sudan, Sao Tome and Principe, Togo, and Chad.
} 
Besides Kenya, Nigeria, Zimbabwe, and South Africa, all the stock exchanges were introduced between the late 80s until recently. Angola is just about to open its own stock exchange market for international investors (Macauhub, 2020). The control countries are those which have not introduced stock exchange markets up to now and these are used as a comparison group for the identification purposes. The goal is to analyse the change in real GDP per capita and its growth from before the implementation of equity capital markets - from the year they were introduced up to post the implementation of equity capital markets.

\subsection{General overview of GDP per capita and capital market size}

Table II illustrates that the size of stock markets is quite small in Sub-Saharan Africa. In comparison, at the time of writing, Apple has a market capitalisation of around 1.8 trillion US dollars, which is 22 times bigger than the mean market capitalisation of the whole Sub-Saharan region over the period analysed (Bloomberg, 2020). In addition, Table III compares real per capita GDP in our country group sample with the US and the EU.

TABLE II - VARIABLES TAKING INTO ACCOUNT THE PERIOD OF 1970-2018 FOR DIFF-INDIFF IN SUB-SAHARAN AFRICA

\begin{tabular}{cccc}
\hline \hline Variable & Obs. & Mean & Std. Dev. \\
\hline GDP per capita & 2,085 & 1,257 & 2,249 \\
GDP per capita growth real & 2,053 & 1.36 & 6.9 \\
Size of capital markets & 199 & $86 \mathrm{bn}$ & $221 \mathrm{bn}$ \\
\hline
\end{tabular}

Note: Values for GDP per capita and size of capital markets are in US\$ currency. Values for GDP per capita growth are as a percentage. The values are calculated based on a panel data of the whole sub-Saharan region over the period 1970-2018. There are only 199 observations for size of capital markets, owing to the relatively low availability of data for this indicator, which aims to capture positive values only. The data was retrieved from the World Bank Indicator repository.

As most stock markets were only introduced very recently in Sub-Saharan Africa, the number of listed companies with a mean of 139 is fairly low. By comparison, the European Union already counted on 3321 companies listed in international stock exchanges by 1975 , with this number increasing to 5,700 by 2018 . Given both the low value of total market capitalisation and the small number of listed companies of the treated countries in comparison to the US or Europe, the extent to which introducing stock 
markets actually has a significant impact on GDP per capita and GDP per capita growth is difficult to ascertain. Should the analysis point to the positive effect of stock market introduction, then this would open up a high potential for a further development of equity capital markets to be associated with considerable gains in GDP per capita.

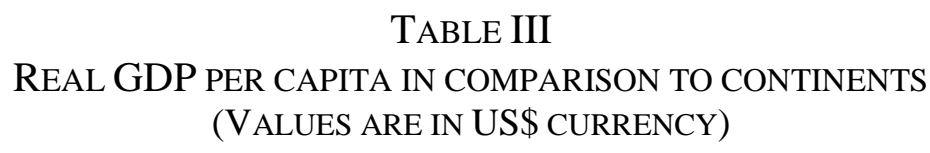

TABLE III

REAL GDP PER CAPITA IN COMPARISON TO CONTINENTS (VALUES ARE IN US\$ CURRENCY)

\begin{tabular}{ccc}
\hline \hline GDPPC & Mean & Std. Dev. \\
\hline EU & 18,028 & 11,574 \\
USA & 29,990 & 17,523 \\
Sub-Sahara & 1,257 & 2,249 \\
Treated countries & 1,811 & 2,576 \\
Control countries & 881 & 1,907 \\
\hline
\end{tabular}

Source: World Bank Indicator Databank. The Sub-Sahara values are calculated based on a panel data set of the whole sub-Saharan region (48 countries) over the period of 1970-2018. Values for EU and US are taking from the WDI directly.

In comparison with the European Union or the United States of America, mean GDP per capita in Sub-Saharan Africa is quite low and displays considerable variation. This indicates that income heterogeneity is substantial within Sub-Saharan countries. To highlight this observation, we consider two countries: the Seychelles and Somalia. While the Seychelles had a GDP per capita of 14,745 US\$ in 2015, Somalia only had a GDP per capita of 293 US\$. This implies that the GDP per capita of the Seychelles is 50 times higher than that Somalia $(14,745 / 293)$. This example shows that the variation of GDP per capita between Sub-Saharan countries is very high. To further emphasize this, we next consider two neighbouring countries: Gabon (which is part of the treated group) and the Democratic Republic of Congo (which is part of the control group). Although these are neighboring countries, the mean GDP per capita is very different for each of them. The Democratic Republic of Congo has a mean of 327 US\$ over this period of nearly 50 year, whereas the amount for Gabon it 5,300 US\$. This suggests that there could be a relationship between GDP per capita levels in real terms and the introduction of equity capital markets.

Furthermore, there is considerable variation in terms of growth of GDP per capita, with the most important variation being recorded in 1997 in Equatorial Guinea - which 
was $140 \%$, due to the discovery of oil and gas in the early 1990s, which subsequently led to it becoming one of Africa's leading oil producers (Frynas, 2004). The lowest GDP per capita growth was recorded in Rwanda during the genocide against the Tutsis in 1994, when income was reduced to nearly half of its size from one year to the next (Hodler, 2019). ${ }^{3}$

The standard deviation of GDP per capita growth in Sub-Saharan Africa is higher when compared with the United States or the European Union, which confirms the higher volatility of GDP growth per capita of Sub-Saharan countries. It is important to emphasise at this point that treated countries which introduced equity capital markets have a higher and less volatile growth rate of GDP per capita. This is clearly demonstrated in the last two rows of Table IV, where the average growth rate of GDP per capita for countries which introduced capital markets is $2.1 \%$. The control group of countries that have not introduced capital markets has an average growth of only $0.8 \%$. In addition, the variation of the GDP per capita growth of the control countries (7.5) exceeds that of the treated countries (5.9).

TABLE IV ${ }^{4}$ - Summary of GDP per capita growth (real), averaged per Continent

\begin{tabular}{ccc}
\hline \hline GDPPCG & Mean & Std. Dev. \\
\hline EU & 1.88 & 1.65 \\
USA & 1.74 & 1.93 \\
Sub-Sahara & 1.36 & 6.93 \\
Treat & 2.15 & 5.90 \\
Control & 0.82 & 7.51 \\
\hline
\end{tabular}

Source: World Bank Indicator Data Bank. The Sub-Sahara values are calculated based on our panel data set of the whole Sub-Saharan region (48 countries) over the period of 1970-2018. Values for the EU and the US are in percentage points and are taken from the WDI directly.

\footnotetext{
3 The cited literature (Hodler, 2019) points to a decrease of 58\% in GDP per capita growth, which is approximately $10 \%$ higher than the decrease in our data from the WDI. We only use WDI data throughout the paper.

4 Note: The values of GDP per capita of Europe and the USA have been taken as country aggregated data points for this period. For example, in Lesotho, capital markets were introduced in 2016, which leaves two observations of GDP per capita for the post period (2017 and 2018 - at the end of the panel). In Somalia, the pre- and post-periods can be less than 10 years, owing to the timing of the introduction of the capital markets. The values in the three columns are then computed as simple averages over the available GDP per capita data for the respective time frame.
} 
TABLE V - PRE-POST GDP PER CAPITA FOR SUB-SAHARAN COUNTRIES WHICH INTRODUCED CAPITAL MARKETS

\begin{tabular}{cccc}
\hline \hline GDPPC & pre 10 years & $\mathrm{t}=0$ & post 10 years \\
\hline Mean & 1,476 & 1,736 & 2,144 \\
Std. Dev & 2,437 & 2,753 & 3,241 \\
Min & 121 & 142 & 150 \\
Max & 12,189 & 12,007 & 16,434 \\
\hline
\end{tabular}

Source: World Bank Indicator Data Bank. In this Table we consider the GDP per capita of the levels of the years prior to the introduction, the year of the introduction, and the years after the introduction of the capital markets. Whenever possible, we include the 10 years before and the ten years after.

Next, we discuss how far GDP per capita and GDP per capita growth differed for the treated countries prior to, during, and after the introduction of equity capital markets. Table V shows GDP per capita for the three levels (US\$) of the treated Sub-Saharan countries for the period ten years prior to the introduction, the year of introduction, and the ten years post the introduction of an international capital market. Although the time effects of growth in GDP are not included in this summary, Table V suggests that the introduction of international stock exchange markets could impact GDP per capita at all levels. The average GDP per capita in the year of introduction amounted to 1,736 US\$ which is around $17.5 \%$ higher than the mean of the 10 years to previous introduction. The value increases by around $23.5 \%$ during the 10 years after implementation to 2,144 US\$. This suggests that there might be a relationship between GDP per capita and the implementation of international stock markets.

Table VI shows that similar results are also found for GDP per capita growth. For example, mean GDP per capita growth 10 years prior to the introduction of capital markets averaged $1.74 \%$, whereas during the 10 years post introduction GDP growth was about $0.3 \%$ points higher. Furthermore, the introduction of capital markets appears to lower the volatility of GDP per capita growth. The standard deviation during the 10 years prior to the introduction of capital markets amounts to $5.2 \%$, whereas during the 10 years post introduction, this deviation only amounts to $2.8 \%$. That is to say, there seems to be less uncertainty about real GDP per capita growth after the introduction of stock exchange markets. This is coherent with the work of Bekaert and Harvey (2006), who analysed the impact of financial liberalisation on the volatility of GDP per capita growth (Bekaert, G., et. al., 2006). Obviously, the highest mean of GDP per capita growth occurs during the 
year of introduction itself, amounting to $4 \%$, which could be a result of the general positive expectations of the economy, although this is, however, also the period with the highest standard deviation, which amounts to $6.5 \%$.

TABLE VI - SUMMARY OF GDP PER CAPITA GROWTH (REAL) OF SUB-SAHARAN COUNTRIES, DIVIDED INTO 10 YEARS PRIOR TO THE INTRODUCTION OF EQUITY CM, T=0, AND 10 YEARS POST INTRODUCTION

\begin{tabular}{cccc}
\hline \hline GDPPCG & pre ( 10 years) & $\mathrm{t}=0$ & post 10 years \\
\hline Mean & 1.74 & 4.02 & 2.06 \\
Std. Dev & 5.24 & 6.45 & 2.85 \\
\hline
\end{tabular}

Source: World Bank Indicator Databank. For each Sub-Saharan country we compute the year-to-year GDP per Capita growth rates during the years prior to, during the year of introduction, and during the years post introduction. For some countries, the pre- and post-periods can be less than 10 years, owing to the timing of the introduction of capital markets. The values in the three columns are then computed as simple averages divided by the available growth data for the respective timeframe.

We check whether the introduction of equity capital markets is associated to higher and positive GDP per capita growth in all the treated countries. During the year of the introduction of international stock exchanges, only 3 out of 23 treated countries, i.e., Zambia, Sudan, and Gabon actually had negative growth rates of $-10 \%,-1.6 \%$, and $-0.2 \%$ respectively. During the 10 years following the introduction, even Sudan and Zambia showed a mean GDP per capita growth of $0.9 \%$ and $3.2 \%$ respectively, whereas the mean growth of Gabon for the 10 years after the introduction of equity capital markets was slightly negative, with $-0.4 \%$. For the remaining countries, the country with the highest mean GDP per capita growth during the year of implementation is Swaziland, with $17.5 \%$. The 10 years post introduction period shows a mean value of $3.2 \%$. Although Swaziland is a small landlocked country, it may have benefitted from its status as a politically-stable location for industries from neighbouring South Africa. Overall, these examples prove the value of testing empirically the impact of the introduction of stock markets on GDP development.

We need to check the time-series properties of the "GDP per capita" and "GDP per capita growth" dependent variables. This is because we tend to think of the introduction of equity capital markets as a permanent (i.e., deterministic) shock to GDP per capita, resulting in GDP per capita being non-stationary. Indeed Appendix Table A2 shows that GDP per capita is integrated of order 1 , but of $\mathrm{I}(0)$ in first differences: that is 
to say that GDP per capita is non-stationary for all three levels, but that growth of GDPPC is stationary. On the basis of these results, we feel comfortable in continuing with the empirical assessment.

\section{EMPIRICAL STRATEGY}

\subsection{Identification}

The empirical analysis consists of a Diff-in-Diff regression. The source of variation arises between those Sub-Saharan countries which actually implemented a stock exchange market (pre and post treatment) and those countries which have not yet implemented international stock exchanges (control group).

The identification strategy centres on estimating $\beta$ and $\gamma$ in the following reduced form expressions ${ }^{5}$ :

(1) $y_{i t}=c+\propto_{i}+\delta_{t}+\beta$ post $_{i t} *$ treat $_{i t}+\boldsymbol{\theta} X_{i t}+\varepsilon_{i t}$,

(2) $\Delta y_{i t}=\zeta_{t}+\gamma$ post $_{i t} *$ treat $_{i t}+\boldsymbol{\psi} X_{i t}+v_{i t}$.

We therefore aim to investigate the magnitude and statistical significance of the $\beta$ and $\gamma$ coefficients. We denote the country by $i$, and time by $t$. Additionally, we have, $y_{i t}$ : GDP per capita; $\Delta y_{i t}$ : GDP per capita growth; c: constant; and $\propto_{i}$ are country fixed effects, where we try to capture time-invariant, country specific effects, such as the existence of natural resources, the quality of institutional framework and regulatory effectiveness, property rights, market autonomy, and the existence of complementary markets and market infrastructure which, if omitted, would bias our coefficients of interest. Furthermore, we also have as definitions, $\beta, \gamma$ : treatment effects; $X_{i t}$ : control variables; $\delta_{t}$ and $\zeta_{t}$ are time fixed effects; and $\varepsilon_{i t}$ and $v_{i t}$ are country time level residuals.

\subsection{Control Variables}

As highlighted above, previous studies found different variables to potentially impact GDP per capita and GDP per capita growth. Their omission could invalidate the common-trend assumption that underlies the Diff-in-Diff strategy and emphasise the need

\footnotetext{
${ }^{5}$ For the analysis we create two dummy "treat\&post" variables, which take the value one for the year that a country introduced stock markets up until 2018 if the country has been treated.
} 
to ensure that control and treatment countries are as comparable as possible (FuchsSchündeln and Funke, 2001). Furthermore, their omission could bias the coefficients of interest, as is outlined next.

Firstly, we control for structural change indicators throughout our analysis. We see that the value added of services during the past 48 years in Sub-Saharan Africa dominated the other sectors, namely agricultural, manufacturing, and industry, with a mean share of $44.4 \%$ of GDP. Similar to the Western World, services appear to become more and more important for Sub-Saharan Africa (see the Appendix for the data statistics on the control variables).

In light of the Baumol disease, we control for the industry shares of the economies. For Baumol highlighted that as economies undergo structural change and the service share becomes more and more important, these economies tend to stagnate in terms of economic growth (Baumol and Bowen, 1966). This is because the service sector is the sector that displays the slowest rate of productivity growth, which becomes more and more important for the total added value of an economy. This highlights that different sectors contribute to economic growth very differently. Given that equity capital tends to be invested in innovative industries, and that Sub-Saharan countries display a high growth rate in the manufacturing sector, there is a concern that omitting the industry, agriculture, and service shares could bias the results.

The introduction of an equity capital market is accompanied by (actual or expected) improvements of institutional frameworks and political stability, as well as by higher contract enforceability and property rights (Merton, 1995). Accounting standards also increase and become more transparent, which is necessary for pricing equity shares. The afore-mentioned factors increase trust and reduce investment risk, which could lead to higher incentives for foreign and/or domestic investors to supply adequately-priced short and long term financing for companies. In turn, this spurs on investment and thus directly affects levels of GDP per capita and growth, as is typically highlighted in the standard neoclassical growth models (Greenwood et al., 1997). To control for this and to ensure that the estimate for the effect of equity capital markets implementation is not biased (upwards), we control for both FDI (as a share of GDP) and domestic credit (as a share of GDP). 
The introduction of stock/equity Capital Markets can also create expectations regarding the independence and effectiveness of policy. Countries that are net suppliers of development aid could be willing to increase their financial aid in response to a higher level of confidence that countries will rightfully and efficiently allocate these funds where they are most needed. Such confidence also directly impacts economic growth (Anyanwu, 2014), especially if financial aid is targeted for innovative programmes. We control for net Official Development Aid in order to avoid a bias in the coefficient of interest. The mean ODA in Sub-Saharan countries amounts to $65 \%$ of their gross capital formation and it should be noted that one country received ODA to the extent of about 40 times its gross capital formation (Sierra Leone).

The advantage of panel data is that fixed effect models can be run to account for time-invariant, country-specific factors, which, if omitted, could also bias the coefficient. For example, time-invariant cultural factors, certain institutions or norms, the existence of natural resources, the effectiveness of the institutional framework, the legal enforcement of property rights, and the expansion of a functioning market framework are all factors which facilitate the implementation of stock markets, which are also positivelycorrelated with GDP per capita in the three levels in terms of growth. Accounting for this is thus crucial to ensure unbiased results.

The other advantage of using a panel dataset is that a full set of time dummies can be included in order to account for the time-fixed effects that affected all the Sub-Saharan countries in the data similarly. This is important, because the pre-post differences in GDP per capita that identify the Diff-in-Diff coefficient could be driven by constant upward time trends. Furthermore, the inclusion of time-dummies helps identify the coefficient consistently and also ensures that the common trend assumption is valid.

\section{RESUlts}

\subsection{GDP Per Capita}

Now to the specific results: Model 1 in Table VII includes time effects and is based on 2,085 observations. The coefficient of interest amounts to 532 US\$ and is statistically significant on the one percent level. For the economic interpretation of this value, we return to the average level of GDP per capita that we observed in Sub-Saharan countries in Table III. The average GDP per capita amounted to 1,257 US\$ which implies 
that the introduction of an equity capital market is associated with a rise of GDP per capita of $532 / 1257=42 \%$. In terms of economics, this is considerable.

Table VII - Regression testing GDPPC in levels

\begin{tabular}{|c|c|c|c|c|c|}
\hline & (1) & (2) & (3) & (4) & (5) \\
\hline post*treat & $\begin{array}{l}532 * * * \\
(-4.19)\end{array}$ & $\begin{array}{l}493^{* * * *} \\
(4.31)\end{array}$ & $\begin{array}{c}852 * * * \\
(6.71)\end{array}$ & $\begin{array}{l}890^{* * * *} \\
(7.24)\end{array}$ & $\begin{array}{r}470^{* * * *} \\
(3.02)\end{array}$ \\
\hline $\begin{array}{c}\text { Services, VA } \\
\text { (\% of GDP) }\end{array}$ & - & - & $\begin{array}{c}1.77 \\
(0.34)\end{array}$ & - & - \\
\hline $\begin{array}{l}\text { Manufacturing, } \\
\text { v.a (\% of GDP) }\end{array}$ & - & - & $\begin{array}{c}47.5^{* * * *} \\
(4.80)\end{array}$ & - & - \\
\hline $\begin{array}{c}\text { Agriculture, } \\
\text { v.a (\% of GDP) }\end{array}$ & - & - & $\begin{array}{c}25.7 * * * \\
(4.19)\end{array}$ & - & - \\
\hline $\begin{array}{l}\text { FDI, net inflows } \\
\text { (\% of GDP) }\end{array}$ & - & - & $\begin{array}{l}-9.76 \\
(-1.96)\end{array}$ & - & - \\
\hline $\begin{array}{l}\text { Domestic credit to } \\
\text { private sector } \\
\text { (\% of GDP) }\end{array}$ & - & - & $\begin{array}{l}48.9 * * * \\
(11.90)\end{array}$ & - & - \\
\hline $\begin{array}{l}\text { Net ODA received } \\
\text { (\% of gross capital } \\
\text { formation) }\end{array}$ & - & - & $\begin{array}{c}-0.5 \\
(-0.22)\end{array}$ & - & - \\
\hline Fixed Effects & Yes & No & Yes & Yes & No \\
\hline Time Effects & Yes & Yes & Yes & Yes & Yes \\
\hline $\mathrm{R}^{2}$ & 0.61 & 0.13 & 0.84 & 0.82 & 0.11 \\
\hline Constant & 728 & 162 & 742 & 1901 & 126 \\
\hline $\mathrm{N}$ & 2,085 & 2,085 & 1,358 & 1,358 & 1,358 \\
\hline
\end{tabular}

Source: World Bank Indicator Databank.

Results for the estimation of Equation (1), including/omitting fixed effects/control variables. Post*treat takes on the value 0 before the introduction of capital markets, and 1 in the year of and all years subsequent to the introduction of capital markets. Post*treat remains 0 in countries which never introduced capital markets (the control group). Countries that introduced capital markets prior to 1970 form part of the treated group throughout 1970-2018 (Nigeria, Somalia, South Africa, and Zimbabwe). The number of observations in Column (3) is lower, due to missing data points in the different control variables. Columns (4)-(5) repeat the exercise in the first two columns, but this time based on the sample in Column (3). T-values in brackets. *** significant at a $1 \%$ level; ** significant at a 5\% level *; significant at a $10 \%$ level. The base year for time effects is 1970 . The base country for the fixed effects is Angola.

Now note that this value is robust for the omission of fixed effects. The $95 \%$ confidence interval of Model 1 with fixed effects lies within 283 US\$ - 781 US\$. The coefficient of Model 2 without fixed effects is 493 US\$ and it stays within this interval. In contrast to our expectations, omitting fixed effects implies that we underestimate the effect of introducing a stock markets. A reason for this could be that the use of fixed effects also captures the status quo of financial literacy, which is presumed to be quite 
low in Sub-Saharan countries. Omitting fixed effects implies omitting this factor, which is the reason why the measured coefficient decreases.

When controlling for variables in Model 3, our coefficient amounts to 852 US\$ and is highly significant at a $1 \%$ level. Note that we test the residuals from this regression for stationarity, to ensure that we do not run into the spurious regression problematic. The results are mixed: Panel unit root tests according to Im, Pesaran and Shin (2003) suggest that residuals are stationary, while the Fisher type unit root test developed by Choi (2001) does not suggest this. We decided to continue the analysis further, given these mixed results. The constant amounts to 742 US $\$$ and the $\mathrm{R}^{2}$ is 0.84 , which implies that the model including control variables, time effects, and fixed effects has the best fit. The estimated coefficient is higher than in Model 1 and 2, which might not be due to the inclusion of control variables, but rather to the smaller sample size of Model 3 (amounting to 1,358 observations). This issue is addressed again further below.

Looking at the proportion of each industry, an increase of 1\% in the GDP share of manufacturing is associated with an increase in GDP per capita of 48 US\$. This compares with 26 US\$ for the equivalent increase of the share for the agricultural. Although the coefficient for value added as share of GDP is slightly positive for services, amounting to 1.77 US\$, it is not significant. In light of Baumol's disease, this suggests that the rise of the service sector is associated with slower economic growth. Our findings on the role of the shares for each industry emphasise that in order to reach higher income levels (in terms of GDPPC), it would be helpful if capital market financing was used to reinforce capital intensive sectors, especially manufacturing. This could help economies overcome this "disease".

The coefficient of foreign direct investment net inflows as a percentage of GDP amounts to - 9.76, which is only significant at the $10 \%$ level. On the other hand, domestic credit for the private sector as a percentage of GDP is highly significant. An increase of $1 \%$ in domestic credit to the private sector as a share of GDP is associated with a rise of 49 US\$ in income. Net ODA has a slightly negative coefficient of -0.5. It should be noted, however, that this coefficient is not significant.

Model 3 has less observations, due to the reduced data availability. For comparability, we opted to estimate Regressions 1 and 2 again, using a subsample of 1,369 observations and then labelled them Model 4 and 5, respectively. In Model 4, 
excluding the control variables, the coefficient amounts to 890 US\$ and is as well significant at a $1 \%$ level. Obviously, omitting control variables leads to an upward bias of the coefficient of interest, however, how does equity capital market financing correlate with the industry structure, for example? A way to perceive this is to consider that investors tend to invest in those projects that exhibit the highest returns, i.e., those which are most innovative and perform best. From this point of view, the manufacturing sector offers greater opportunities than services. Accordingly, the higher the manufacturing share, the greater the amount of financing that is attracted through the equity capital markets. Furthermore, one should consider the share of domestic credit - where the more the financial markets are developed, the lower is the effect of introducing an additional form of financing, such as equity capital markets. When leaving out controls, the coefficient is upwards biased, due to the fact that equity capital markets tend to be implemented in those economies that already have well-established financial markets. In addition, the constant increases in value to 1,901 US\$. By omitting country fixed effects in Model 5, it can now be seen that the coefficient amounts to just 470 US\$ - in other words, leaving out country fixed effects appears to bias our results downward. The $\mathrm{R}^{2}$ in Model 5 is 0.11 . The best fit is for Model 3 - with an $\mathrm{R}^{2}$ of 0.84 , including the control variables.

\subsection{GDP per Capita growth}

We now undertake a regression testing of GDP per capita growth. As we are analysing a differenced value, we omit the constant and fixed effects. In Model 6 we exclude the control variables. Table VIII shows a positive coefficient of 0.47 , which demonstrates that when compared to the period prior to the introduction of equity capital markets, the treated countries exhibit a higher coefficient of capita growth. However, the model implies that the introduction of equity capital markets is not associated with a statistically-significant higher level of GDP per capita growth.

Similar to our analysis of GDP per capita in three levels, we now repeat the regression, but this time including our control variables. Model 7 has a higher coefficient for post*treat than Model 6 at a 5\% significance level, which could be a result of the lower sample size of 1,340 observations. The treated countries exhibit a GDP growth 
which is 1 percentage point greater than the period prior to the introduction of equity capital markets.

We now carry out the regression of Model 6 with the same sample that is used in Model 7, in order to make it comparable. A higher coefficient of interest is observed when the control variables are excluded, which is highly significant on a $1 \%$ level. Once again, the reason for this upwards trend could be that the capital markets correlate with the industry structure. It should be mentioned that not controlling for specific sectors, FDI, domestic credit, and ODA, could bias the estimation of this coefficient.

Table VIII - GDP Per Capita Growth during the Post Period

\begin{tabular}{|c|c|c|c|}
\hline & (6) & (7) & $(8)$ \\
\hline postxtreat & $\begin{array}{c}0.47 \\
(1.26)\end{array}$ & $\begin{array}{l}0.91 * * \\
(2.51)\end{array}$ & $\begin{array}{c}0.99 * * * \\
(2.83)\end{array}$ \\
\hline $\begin{array}{c}\text { Services } \\
\text { v.a (\% of GDP) }\end{array}$ & - & $\begin{array}{c}0 \\
(-0.05)\end{array}$ & - \\
\hline $\begin{array}{l}\text { Manufacturing, } \\
\text { v.a (\% of GDP) }\end{array}$ & - & $\begin{array}{l}-0.05^{*} \\
(-1.72)\end{array}$ & - \\
\hline $\begin{array}{c}\text { Agriculture, } \\
\text { v.a (\% of GDP) }\end{array}$ & - & $\begin{array}{c}-0.02 \\
(-1.59)\end{array}$ & $\begin{array}{l}- \\
-\end{array}$ \\
\hline $\begin{array}{l}\text { FDI, net inflows } \\
\text { (\% of GDP) }\end{array}$ & - & $\begin{array}{c}0.012 \\
(-0.52)\end{array}$ & - \\
\hline $\begin{array}{l}\text { Domestic credit to } \\
\text { private sector } \\
(\% \text { of GDP })\end{array}$ & - & $\begin{array}{l}0.003 \\
(-0.39)\end{array}$ & - \\
\hline $\begin{array}{l}\text { Net ODA received } \\
\text { (\% of gross capital } \\
\text { formation) }\end{array}$ & - & $\begin{array}{l}-0.003 \\
(-2.16)\end{array}$ & - \\
\hline Fixed Effects & No & No & No \\
\hline Time Effects & Yes & Yes & Yes \\
\hline $\mathrm{R}^{2}$ & 0.08 & 0.13 & 0.13 \\
\hline $\mathrm{N}$ & 2,053 & 1,343 & 1,343 \\
\hline
\end{tabular}

Source: World Bank Indicator Databank. Results for the estimation of Equation (2), whilst including/omitting control variables. Post*treat assumes the value 0 before the introduction of capital markets, and 1 during and after the year of the introduction of capital markets. This value remains 0 for those countries that never introduced capital markets (the control group). Countries that introduced capital markets prior to 1970 form part of the treated group for the period of 1970-2018 (Nigeria, Somalia, South Africa and Zimbabwe). The number of observations in Column (2) is lower, due to missing data points for the different control variables. Column (3) repeats the exercise in the first column, but this time based on the sample in Column (2). The t-values are in brackets. *** significant at a $1 \%$ level; ** significant at a $5 \%$ level $*$; significant at a $10 \%$ level; 


\subsection{Time varying effects}

Next we aim to analyse whether the introduction of equity capital markets had time-varying effects during the 10 years post the introduction of stock markets in the treated countries.

Similar to the research of Fuchs-Schündeln \& Funke (2001) and Naceur (2008), we create a dummy variable for every year: for instance, eq_imp0 assumes the value of 1 during the year of the implementation of a stock market, and 0 in all other years. Post_impi1 assumes the value of 1 one year after the introduction of capital markets and 0 otherwise - and so on for each year up until Year 10. We compare the regression including the dummies with our results from before when we only specified the post period of equity market implementations. Furthermore, we also compare our results with those of the literature which estimated similar regressions, but this time taking into consideration the banking sector, stock markets, and debt markets as indicators for the development of capital markets.

The identification strategy builds on the following reduced form equation:

(3) $y_{i t}=c+\alpha_{i}+\delta_{t}+\beta_{t}$ post_imp $p_{i t} *$ treat $_{i t}+\gamma X_{i t}$

where "post_impit" takes on the value of 1 during Year $t$ after implementation, and value 0 for all other years (as described above). The remaining parameters remain the same as above.

Table IX shows a positive $\beta$ coefficient for the same year of the introduction of equity capital markets, although it is not statistically significant. The introduction of equity capital markets for the treated countries is associated with a 408 US\$ growth of GDP per capita in levels during the year of introduction. This positive effect, albeit in levels, is coherent with the results of Fuchs-Schündeln and Funke (2001), who regressed real GDP per capita growth on stock market liberalisation indices for a panel data of 27 countries. Naceur et al. (2008) assessed two similar cases, based on the MENA region countries and a sub-sample consisting of seven countries. Interestingly, their results are rather different - the growth rate of GDP per capita during the year of liberalisation is negative and is statistically insignificant and no statistically-significant effects were found in this case. 
TABLE IX - ESTIMATING THE COEFFICIENT OF THE RESPONSE OF GROWTH TO THE INTRODUCTION OF CAPITAL MARKETS FOR EACH YEAR POST-INTRODUCTION

\begin{tabular}{|c|c|c|c|}
\hline GDPPC & Coefficient & \multicolumn{2}{|c|}{ [95\% Conf. Interval] } \\
\hline postimp0 & $\begin{array}{c}408 \\
(1.43)\end{array}$ & -153 & 969 \\
\hline postimp1 & $\begin{array}{c}596^{* *} \\
(2.1)\end{array}$ & 35.9 & 1155 \\
\hline postimp2 & $\begin{array}{l}596 * * \\
(2.15)\end{array}$ & 52.1 & 1139 \\
\hline postimp3 & $\begin{array}{l}685^{* * *} \\
(2.4)\end{array}$ & 125 & 1244 \\
\hline postimp4 & $\begin{array}{l}745^{* * *} \\
(2.61)\end{array}$ & 186 & 1305 \\
\hline postimp5 & $\begin{array}{l}772 * * * \\
(2.71)\end{array}$ & 213 & 1332 \\
\hline postimp6 & $\begin{array}{l}95.9 \\
(0.33)\end{array}$ & -482 & 674 \\
\hline postimp7 & $\begin{array}{l}177 \\
(0.6)\end{array}$ & -402 & 755 \\
\hline postimp8 & $\begin{array}{c}259 \\
(0.88)\end{array}$ & -319 & 837 \\
\hline postimp9 & $\begin{array}{c}-9 \\
(-0.03)\end{array}$ & -586 & 568 \\
\hline postimp10 & $\begin{array}{l}-130 \\
(-0.04)\end{array}$ & -706 & 447 \\
\hline $\begin{array}{c}\text { Services, } \\
\text { v.a }(\% \text { of GDP })\end{array}$ & $\begin{array}{c}5.66 \\
(1.07)\end{array}$ & -4.74 & 16.1 \\
\hline $\begin{array}{c}\text { Manufacturing, v.a ( } \% \text { of } \\
\text { GDP) }\end{array}$ & $\begin{array}{c}61.7 \\
(6.26)\end{array}$ & 42.3 & 81 \\
\hline $\begin{array}{l}\text { Agriculture, v.a (\% of } \\
\text { GDP) }\end{array}$ & $\begin{array}{l}22.1 \\
(3.57)\end{array}$ & 9.93 & 34.2 \\
\hline $\begin{array}{l}\text { FDI, net inflows } \\
\text { (\% of GDP) }\end{array}$ & $\begin{array}{c}-9.9 \\
(-1.96)\end{array}$ & -19.8 & 0.02 \\
\hline $\begin{array}{l}\text { Domestic credit to } \\
\text { private sector (\% of GDP) }\end{array}$ & $\begin{array}{c}52.3 \\
(12.45)\end{array}$ & 44.1 & 60.6 \\
\hline $\begin{array}{l}\text { Net ODA received } \\
\text { (\% of gross capital } \\
\text { formation) }\end{array}$ & $\begin{array}{c}-0.03 \\
(-0.14)\end{array}$ & -0.5 & 0.43 \\
\hline Fixed Effects & Yes & - & - \\
\hline Time Effects & Yes & - & - \\
\hline $\mathrm{R}^{2}$ & 0.84 & - & - \\
\hline $\mathrm{N}$ & 1,353 & - & - \\
\hline
\end{tabular}

Note: Source: World Bank Indicator Databank. T-values in brackets. Results for the estimation of Equation (3), including/omitting fixed/time effects and control variables, where "post_impit" takes on a value of 1 in Year $t$ after implementation, and a value of 0 in all other years (as described above). This value remains 0 in those countries that never introduced capital markets (the control group). Countries that introduced capital markets prior to 1970 form part of the treated group throughout 1970-2018 (Nigeria, Somalia, South Africa, and Zimbabwe), with the sample consideration that we noted for Table $\mathrm{V}$ remaining valid for this case, with $\mathrm{T}$-values in brackets. *** significant at a $1 \%$ level; ** significant at a $5 \%$ level *; significant at a $10 \%$ level; .

To obtain a better visualisation of the patterns of the coefficients, let us consider Figure 1, where it can be observed that the coefficient turns out to be significant at a 5\% 
level, starting from the first year after the introduction of equity capital markets. It can thus be deducted from the fact that the lower red line (which marks the bottom of the $95 \%$ interval) does not cross the zero-line anymore. Furthermore, the coefficient rises over time, i.e., it appears that the introduction of equity capital markets is associated with a higher level of GDP per capita, but only with a certain time lag. It is worth noting that the coefficients even attain a $1 \%$ significance level during the fourth and fifth year after the introduction of an equity capital market and that they attain a peak in the fifth year, with a value of 772 US\$. In comparison, Fuchs-Schündeln and Funke (2001) proved in their study that the effect of market liberalisation on GDP growth attained a peak in Year 4.

FIGURE 1 - Scatter plot of the Coefficient for respective years and their $95 \%$ confidence interval.

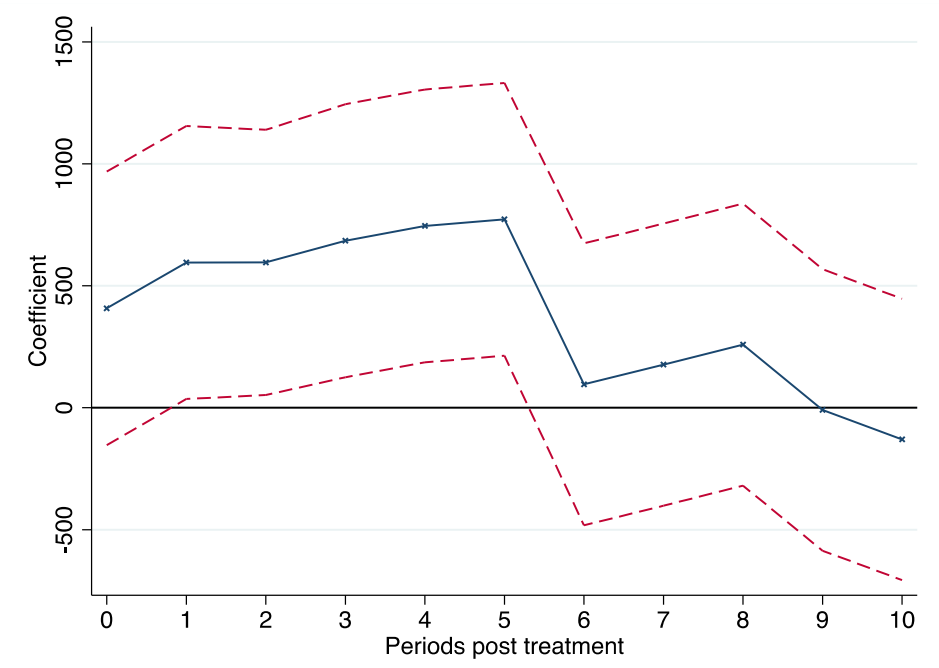

Source: World Bank Indicator Databank. The X-axis displays each year post introduction of stock exchange markets for the treated countries. The Y-axis displays the coefficients estimated in Equation 3 and its respective significance intervals.

Our coefficients of interest follow an inverse U-shape, i.e., they appear to be limited in time, as the coefficient decreases considerably in Year 6 to 96 US\$, and is not significant for this year and the following years. The coefficient increases again to 176 US\$ and 259 US\$ in Years 7 and 8 respectively, whereas it assumes a negative value in Years 9 and 10 (it should be noted, however, that none of these estimates are statistically significant anymore). These results could signify that the capital inflows after the introduction of equity capital markets are more portfolio and short term orientated, as suggested by Naceur et al. (2008) in their study, which considers market liberalisation as a whole. 
It should be noted that the underlying regression used to estimate these coefficients includes control variables, which turn out to be crucial for generating statistically-significant estimates of the time-varying coefficients. In general, it can be said that the results of our study are, in general, very much in line with our previous Diffin-Diff findings for the analysis of the effect of the introduction of equity capital markets. Both regressions prove that the introduction of equity capital markets is positively correlated with GDP per capita. The findings of this additional exercise serve to emphasise that these effects follow an inverse U-shape.

\section{Conclusion}

We assessed the effect of the introduction of international stock exchange markets in the Sub-Saharan region, using a panel data set ranging from 1970 to 2018, for a sample of 48 Sub-Saharan countries. Out of these 48 countries, 23 countries introduced international stock exchange markets and are part of the treated group, whereas the remaining 25 countries have not yet introduced such markets and form the control group.

First, we conduct a Diff-in-Diff analysis. Our models differ in the sense that we include/exclude time fixed effects, country fixed effects, and control variables to assess the impact of omitting certain variables. Having left out these control variables, our regression shows that the introduction of equity capital markets is associated with a rise of GDP per capita of approximately $42 \%$ (of the average of Sub-Saharan countries, derived over the period of nearly 50 years).

We repeat the regression on a subsample due to the lower existence of data availability, but this time with the inclusion of fixed and time effects control variables which demonstrates that the introduction of stock markets is associated with a rise of GDP per capita of $850 \mathrm{US} \$$. This model fits our prediction best with an $\mathrm{R}^{2}$ of 0.84 . Furthermore, our analysis posits that those countries that implemented equity capital markets show a better performance in terms of the development of GDP per capita.

Second, we analyses the effect of the introduction of equity capital markets on each single year during the post period, up until Year 10, with the aim to investigate the dynamics of the adjustment process, based on the findings of our first analysis. We conclude that although the effect is not significant for the actual year of the introduction of equity capital markets, this implementation is correlated with GDP per capita in the 
form of an inverse U-Shape, where GDP per capita increases during the following five years. From Year 6 onwards, GDP per capita decreases again - which implies that the effect is rather of short term relevance, than of long term relevance. Overall, this observation confirms our previous results - namely that countries benefit from economic growth when they introduce capital markets.

For future research, we suggest the study of other promising control variables such as trade openness and the efficiency of institutional frameworks - which would probably provide more accurate results when it comes to estimating the effect of introducing capital markets on economic growth. However, at the time of conducting our research, these country-specific indices were not available for our sample of Sub-Saharan countries. We anticipate that future data availability will enable research to take into account additional country-specific but time-varying control variables, with the aim to quantify the importance of equity capital markets in a consistent and unbiased way.

\section{REFERENCES}

Acharya, V. \& Bo, L. (2019). “Establishing viable capital markets”, CGFS Papers, No.62, Bank of International Settlements.

Anyanwu. J. (2014). "Factors affecting economic growth in Africa: are there any lessons from China?" African Development Review, 26, 468-493.

Baumol, W., Bowen, W. (1966). Performing Arts, The Economic Dilemma: a study of problems common to theatre, opera, music, and dance. Cambridge, Mass.: M.I.T. Press.

Bekaert, G., Harvey, C, Lundblad, C. (2006). "Growth volatility and financial liberalization”, Journal of International Money and Finance, 25 (3), 370-403.

Bloomberg. (2020). Market Capitalization of Apple Inc., \{Online\}, Available at: https://www.bloomberg.com/quote/AAPL:US, Accessed: 21/09/2020.

Choi, I. (2001). "Unit root test for panel data", Journal of International Money and Finance, 20 (2), 249-272.

Coulibali, S. \& Gapka L. (2017). "The Role of Property Rights in the Relationship between Openness to International Capital Flows and Economic Growth in SubSaharan Africa Countries: An Estimate from Non-Stationarity Panel Data", International Business and Economics Research Journal, 8 (2), 77-88. 
Cuza, A. (2012). Can Stock Market Development Boost Economic Growth? Empirical Evidence from Emerging Markets in Central and Eastern Europe, Procedia Economic and Finance 3, 438-444.

Fuchs-Schündeln, N. \& Funke, N. (2001). "Stock Market Liberalizations: Financial and Macroeconomic Implications”. IMF Working Paper No. 01/193,

Frynas, J. (2004). “The Oil Boom in Equatorial Guinea”, African Affairs, 103 (413), 527546.

Greenwood, J. \& Smith, B. (1997). "Financial markets in development, and the development of financial markets", Journal of Economic Dynamics and Control, 21(1), 145-181.

Holder, R. (2018). "The Economic Effects of Genocide: Evidence from Rwanda", Journal of African Economies, 28 (1), 1-17.

Im, K., Pesaran, M. \& Shin, Y. (2003). "Testing for unit root in heterogeneous panels", Journal of Econometrics, 115 (1), 53-74.

Levine, R. \& Zervos, S. (1998). "Stock Market, Banks, and Economic Growth", American Economic Review, 88 (3), 537-558.

Macauhub (2020). Angolan and London Stock Exchanges will prepare companies to privatize, \{Online\}, https://macauhub.com.mo/2020/03/06/pt-bolsa-de-valores-deangola-e-de-londres-vao-preparar-empresas-a-privatizar/, Accessed: 21/07/2020.

Merton, R. (1995). "Financial innovation and the management and regulation of financial institutions", Journal of Banking and Finance. 19 (3-4), 461-481.

Naceur, B., Ghazouani, S., Omran M. (2008). "Does stock market liberalization spur financial and economic development in the MENA region?" Journal of Comparative Economics, 36(4), 673-693.

Nowbutsing, B. \& Odit, M. (2009). "Stock Market Development and Economic Growth: The Case of Mauritius", International Business \& Economics Research Journal, 8 (2).

Romer, D. (1996). Advanced Macroeconomics, The Solow Growth Model p. 6-45.

Yiew, T. \& Lau, E. (2018). "Does foreign aid contributes to or impeded economic growth?” Journal of International Studies, 11 (3), 21-30. 


\section{APPENDIX}

TABLE A1 - CONTROL VARIABLES

\begin{tabular}{cccc}
\hline \hline Variable & Obs & Mean & Std. Dev. \\
\hline Service value added (\% GDP) & 1,819 & 44.4 & 11 \\
Manufacturing value added (\% GDP) & 1,728 & 10.4 & 5.90 \\
Agriculture value added (\% GDP) & 1,930 & 25.9 & 15.5 \\
Foreign Direct Investment (\% GDP) & 2,043 & 3.07 & 7.92 \\
Domestic Credit to Private Sector (\% GDP) & 1,948 & 17.8 & 19.2 \\
Net ODA received (\% of gross capital & & & \\
formation) & 1,772 & 64.5 & 129 \\
\hline
\end{tabular}

Source: World Bank Indicator Data Bank. The values are calculated based on our panel data of the whole Sub-Saharan region over the period of 1970-2018. The number of observations differs, because the availability of data begins at different points in time for the different countries (an unbalanced panel).

\section{TABLE A2 - UnIT RoOT RESULTS}

\begin{tabular}{clcccccc}
\hline \hline & Class. & \multicolumn{3}{c}{ Im, Pesaran \& Shin } & \multicolumn{2}{c}{ Fisher } & \\
\cline { 2 - 7 } & & T-Stat & Prob. & Unit Root & T-Stat & Prob. & Unit Root \\
\cline { 2 - 8 } GDPPC & Control & 1.75 & 0.96 & $\mathrm{I}(1)$ & 1.91 & 0.97 & $\mathrm{I}(1)$ \\
& Treated & -1.06 & 0.14 & $\mathrm{I}(1)$ & 0.18 & 0.57 & $\mathrm{I}(1)$ \\
\cline { 2 - 7 }$\Delta$ GDPPC & Control & -20.68 & 0 & $\mathrm{I}(0)$ & -7.15 & 0 & $\mathrm{I}(0)$ \\
\multirow{2}{*}{$\begin{array}{c}\text { Residuals } \\
\text { from }\end{array}$} & Control & -2.14 & 0.02 & $\mathrm{I}(0)$ & 0.02 & 0.51 & $\mathrm{I}(1)$ \\
Model 3 & Treated & -1.74 & 0.04 & $\mathrm{I}(0)$ & 0.39 & 0.65 & $\mathrm{I}(1)$ \\
\hline
\end{tabular}

Note: Dickey Fuller Test based on Im, Pesaran and Shin (2003), which tests H(0): All panels have a unit root against H(1): Some panels are stationary. The results from Choi's (2001) Fisher-type unit root tests for $H(0)$, where all panels contain unit roots against $\mathrm{H}(1)$ and at least one panel is stationary. 